\title{
Diel horizontal migration of Mesopodopsis slabberi (Crustacea: Mysidacea) in Algoa Bay, southern Africa
}

\author{
P. Webb, T. H. Wooldridge* \\ University of Port Elizabeth, Institute for Coastal Research and Department of Zoology, PO Box 1600, Port Elizabeth 6000, \\ South Africa
}

\begin{abstract}
The mysid shrimp Mesopodopsis slabberi (van Beneden), exhibited a diel pattern of onshore-offshore movement off Sundays River beach, South Africa. Shoreward migration at sunset resulted in the presence of relatively high numbers of mysids after dark behind the breaker line (ca $6 \mathrm{~m}$ water depth) compared to further offshore. At first light, $M$. slabberi migrated back to deeper water (>15 m) where it remained during daylight. The nocturnal presence of mysids behind the breakers is interpreted as a response to increased concentration of phytoplankton, principally Anaulus australis Drebes and Schulz, which outwelled from the inner surfzone through rip current activity. Consumption by $M$. slabberi was estimated to be $51 \mathrm{~g} \mathrm{C} \mathrm{d}^{-1}$. On an annual basis, this approximated to $70 \%$ of total available carbon consumed by the macrofaunal trophic assemblage in the Sundays River surfzone.
\end{abstract}

\section{INTRODUCTION}

Studies on the migration of zooplankton usually focus on stimuli inducing vertical migration and the adaptive significance of such movements (Enright 1977, Enright \& Honegger 1977, Ringelberg 1980, Angel 1985). Other types of directed movement, i.e. movements resulting in patchy, non-random horizontal patterns (Hutchinson 1967), shore avoidance (Siebeck \& Ringelberg 1969), daytime swarming followed by nocturnal dispersal (Hamner \& Carleton 1979), and long distance horizontal migrations (Hamner \& Hauri 1981), have received comparatively less attention.

In mysids, horizontal migration has been recorded for Mysis relicta in Lake Tahoe, Donner Lake and Fallen Leaf Lake in California/Nevada, USA (Morgan \& Threlkeld 1982). Size dependent movements in these mysids were related to dietary changes during ontogenetic development. Williams \& Collins (1984) investigated the seasonal distribution and variability in abundance of Schistomysis spiritus in the Bristol Channel, UK, and proposed that the horizontal movements of these mysids were affected by a number of biotic and physical variables acting in concert. Clutter (1967) investigated the possible causes and functions of the

\footnotetext{
- Addressee for correspondence
}

zonation of the numerically dominant mysid species in La Jolla Bight, California, USA, and suggested that zonation may have developed in response to food availability patterns imposed by nearshore circulation systems.

Circulation patterns determine the distribution of detritus and phytoplankton off sandy beaches in Algoa Bay, South Africa (Talbot \& Bate 1986). The diatom Anaulus australis Drebes \& Schulz (formerly identified as $A$. birostratus), accumulates in surfzone surface waters during daylight, but begins to disperse in the late afternoon. Surface accumulation of cells is due to their positive buoyancy, presumably by adherence to air bubbles and subsequent concentration by waves advecting shorewards. After dark, the concentration of $A$. australis in the water column decreases significantly as cells change their life mode from planktonic to epipsammic (Talbot \& Bate 1988a). Part of the inshore accumulation of cells, as well as surfzone detritus, is transported seawards by rip currents, depositing suspended material behind the breaker line as current velocities decrease and dissipate (Clutter 1967, Talbot \& Bate 1988b). These currents thus distribute food produced in the inner surfzone and make it available to grazers beyond the breaker line.

Wooldridge (1983) recorded large numbers of Mesopodopsis slabberi (Van Beneden), at night, only 
behind the breaker line in Algoa Bay, and suggested that the nocturnal appearance of mysids is a reflection of a general onshore movement to exploit a rich food supply in the form of outwelling diatoms. This study investigates the nature of the diel horizontal migration of $M$. slabberi and attempts to explain changes in distribution in terms of food availability and predator avoidance. An attempt is also made to quantify the possible effect of mysid grazing pressure on Anaulus australis, which accounts for over $95 \%$ of total annual primary production in the Sundays River surfzone system (Campbell \& Bate 1988).

\section{MATERIALS AND METHODS}

Diel variation in distribution of Mesopodopsis slabberi was investigated off Sundays River beach in waters directly influenced by surf circulation cells (Fig. 1). This corresponds to the zone extending from the breaker line to the $10 \mathrm{~m}$ depth contour (McLachlan 1983).

Stations were positioned in water of $6,10,15$ and $20 \mathrm{~m}$ depth using marker buoys (Fig. 1). Two separate $24 \mathrm{~h}$ sessions (February and March 1985) were completed at the 6 and $10 \mathrm{~m}$ stations. Replicate samples were collected every $3 \mathrm{~h}$ at each station and on each occasion. Two further sets of samples were collected in late afternoon and after dark at each of the 4 depth

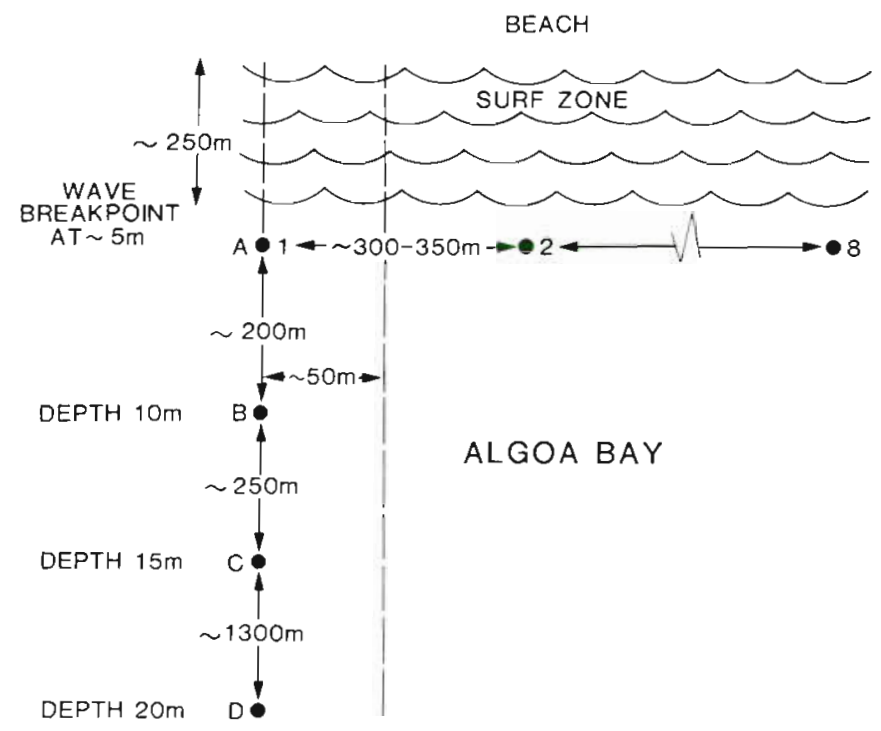

Fig. 1 Diagrammatic representation of shore-normal and shore-parallel sampling stations off Sundays River beach, Algoa Bay, southerm Africa. A to D indicate the relative position of stations at the $6,10,15$ and $20 \mathrm{~m}$ depth zones. Replicate samples were collected $50 \mathrm{~m}$ to the east of this transect line. 1 to 8 indicate the locality of the series of stations sampled continuously over $2.5 \mathrm{~km}$ zones in April and September 1986. A fifth set of samples was obtained at 3 to $5 \mathrm{~h}$ intervals between 14:00 h on 22 November and 09:00 h on 24 November 1985 at the $6 \mathrm{~m}$ station. Nocturnal longshore distribution was determined on 2 occasions (April and September 1986j. Eight and 7 stations, respectively, were sampled along the $6 \mathrm{~m}$ depth contour over a distance of $2.5 \mathrm{~km}$. Sampling was continuous on each occasion with tow distances monitored from the beach using a vehicle odometer.

Sub-surface and near-bottom samples were collected at every station using 500 um mesh WP 2 plankton nets (57 cm diam.) fitted with Kahlsico 005 WA130 flowmeters. Nets were also attached to separate surface floats to allow for depth regulation. Nets were towed at ca $1.5 \mathrm{~m} \mathrm{~s}^{-1}$ behind a $6 \mathrm{~m}$ skiboat fitted with an echo sounder. On occasions, a small quantity of sand was present in the bottom net and attested to the general proximity of the net to the substrate. During each $3 \mathrm{~min}$ tow, ca $70 \mathrm{~m}^{3}$ of water was filtered.

Daylight sampling along the shore-normal transect line and within $1.5 \mathrm{~m}$ of the substrate was carried out on 2 occasions (August and September 1986) by SCUBA divers using hand nets. Sheltered areas under overhangs and in gullies of rocky reefs located in water of 15 and $20 \mathrm{~m}$ depth were sampled, as well as the sandy floor up to $50 \mathrm{~m}$ distant from reef outcrops.

In the laboratory, samples were resuspended in known volumes of water and subsamples taken from the middle depth of the suspension in order to facilitate counts of adult and juvenile mysids under $40 \times$ magnification. Five subsamples were taken in each case and an average number of animals in each size class obtained. This number was used to calculate the number of mysids present per cubic metre of water at the time of sampling.

Offshore transect data were analysed using BMDP (Biomedical Data Processing) univariate (1V) and multivariate (2V) statistical packages and by Tukey multiple comparison procedure. Longshore data were subjected to Kolmogorov-Smirnov analysis.

\section{RESULTS}

Pooled offshore data indicated a statistically significant difference in the number of mysids present during daylight, sunset, dark and sunrise $(F=3.42$; $\mathrm{p}<0.05)$. Although the data suggested an increase in the number of mysids after dark, Tukey analysis of similarities and differences between groups indicated no significant difference between the number of anjmals taken in sunset, dark and sunrise samples. No mysids were taken during daylight in WP 2 plankton nets. 
Shortly before sunset, few or no mysids were recorded at the shallowest station behind the breaker line. At this time, mysids were usually present in surface and nearbottom samples at the $10 \mathrm{~m}$ station. This contrasted to the pattern of horizontal distribution recorded after dark. Analysis of pooled data from nocturnal samples indicated significant differences $(F=5.5 ; p<0.05)$ between numbers of mysids taken at different depths with the greatest number of animals taken at the $6 \mathrm{~m}$ depth station (immediately behind the breaker line and ca $250 \mathrm{~m}$ offshore from the beach). Fewer animals were caught at $10 \mathrm{~m}$ depth (ca $200 \mathrm{~m}$ beyond the breakers) and no mysids were netted at the 15 and $20 \mathrm{~m}$ stations, i.e. further than $500 \mathrm{~m}$ offshore of the breaker line. The number of mysids varied greatly between sampling sessions, but time averaged values of 337 mysids $\mathrm{m}^{-3}$ water at the $6 \mathrm{~m}$ depth contour throughout the night, compared to $42 \mathrm{~m}^{-3}$ at the $10 \mathrm{~m}$ depth contour, illustrate the trend. At sunrise, mysids were more abundant at the $10 \mathrm{~m}$ station and by full light, no mysids were taken in the water column out to the deepest station sampled. This pattern is clearly evident in Table 1 which presents data for one of the $24 \mathrm{~h}$ series.

A comparison between surface and near-bottom samples collected after dark at 6 and $10 \mathrm{~m}$ stations indicate significantly greater numbers of mysids nearer the substrate (Students t-test $=2.21 ; \mathrm{p}<0.05 ; \mathrm{n}=43$ ) . On one occasion, the ratio increased to $1: 18$ (sur-

Table 1. Mesopodopsis slabberi. Offshore distribution (no. $\mathrm{m}^{-3}$ ) sampled over $24 \mathrm{~h}$ during March 1985 behind the breaker line at 5 and $10 \mathrm{~m}$ depth stations. Data refer to samples collected along each shore-normal transect line illustrated in Fig. 1

\begin{tabular}{|llrr|}
\hline Time & Sample depth & $5 \mathrm{~m}$ & $10 \mathrm{~m}$ \\
\hline Daylight & Surface & 0 & 0 \\
& & 0 & 0 \\
& Near bottom & 0 & 0 \\
Sunset & & 0 & 0 \\
& Surface & 0 & 60 \\
Night & Near bottom & 0 & 8 \\
& & 0 & 94 \\
& Surface & 1 & 12 \\
Sunrise & Near bottom & 127 & 51 \\
& & 474 & 27 \\
& Surface & 113 & 38 \\
& & 31 & 130 \\
Daylight & Near bottom & 0 & 123 \\
& & 214 & 463 \\
& Surface & 2 & 248 \\
& & 0 & 0 \\
& Near bottom & 0 & 0 \\
& & 0 & 0 \\
& & 0 & 0 \\
\hline
\end{tabular}

face:bottom) at the shallow station. These data suggest a generally demersal distribution of the visiting population after dark.

Size class composition of mysids varied; in February and March 1985, juveniles (< $8.0 \mathrm{~mm}$ length) were mainly represented. Juveniles were relatively less abundant on the other occasions. Although abundance of juveniles in samples may reflect general size composition at the time of sampling for the population generally, size selective swarming of mysids is noted in the literature (Clutter 1969, Wittman 1977. Mauchline 1980). Differences in size class composition between swarms is attributed to differential swimming speed between large and small individuals.

Continuous sampling along the $2.5 \mathrm{~km}$ transect behind the breaker line did not establish discrete patterns in adult and juvenile distribution (Table 2). Combined numbers $\mathrm{m}^{-3}$ revealed a continuous distribution of Mesopodopsis slabberi $\left(\mathrm{D}_{0.05 .8 .985}=143\right.$; $\left.\mathrm{p}<0.05\right)$, with mysids absent from this zone during daylight.

Sampling of water in gullies and under overhangs of ca $2 \mathrm{~m}$ high reef at $15 \mathrm{~m}$ depth, using SCUBA and a hand net, yielded rich concentrations of Mesopodopsis slabberi. Ten sweeps of the $15 \mathrm{~cm}$ diam net, in both gullies and under overhangs, yielded an average of 1777 mysids of both sexes and all size classes. Sampling at a similar reef in water $20 \mathrm{~m}$ deep yielded an average of only 20 mysids $10^{-1}$ sweeps of the net. Samples taken as close as possible to the sandy substrate in the area immediately surrounding each reef, and the sandy bay floor $50 \mathrm{~m}$ shorewards of each reef, seldom yielded mysids, except on rare occasions when individual animals were taken.

\section{DISCUSSION}

Mesopodopsis slabberi is abundant in inshore waters of Algoa Bay, South Africa, where concentrations exceeding $15000 \mathrm{~m}^{-3}$ have been recorded (Wooldridge 1983). During the day, mysids were absent in shallow areas behind the breaker line. In the late afternoon,

Table 2. Mesopodopsis slabberi. Longshore distribution (no $\mathrm{m}^{-3}$ ) sampled at night on 2 occasions behind the breaker line in water of $6 \mathrm{~m}$ depth. Relative position of stations illustrated in Fig. 1

\begin{tabular}{|lrrrrrrrr|}
\hline $\begin{array}{l}\text { Sample } \\
\text { depth }\end{array}$ & 1 & 2 & 3 & 4 & 5 & 6 & 7 & 8 \\
\hline Surface & 70 & 49 & 99 & 126 & 46 & 38 & 30 & 33 \\
Near bottom & 99 & 45 & 117 & 113 & 94 & 37 & 33 & 36 \\
Surface & 48 & 49 & 31 & 69 & 88 & 21 & 146 & - \\
Near bottom & 110 & 259 & 178 & 205 & 183 & 121 & 170 & - \\
\hline
\end{tabular}


they migrated onshore from deeper bay waters $(>15 \mathrm{~m})$, covering a horizontal distance of ca $500 \mathrm{~m}$. After dark, M. slabberi was present in water 6 to $10 \mathrm{~m}$ deep, with significantly greater numbers immediately behind the breakers than further out in the $10 \mathrm{~m}$ depth zone. Mysids were also more abundant nearer the substrate than in near-surface waters. At first light, $M$. slabberi migrated back offshore.

The nocturnal zonation of Mesopodopsis slabberi may be interpreted as a response to the pattern of food availability. A distinctive feature of the dominant surfzone diatom Anaulus australis is its neustonic mode of life, presumably as a result of cell adherence to air bubbles during the day (Talbot and Bate 1988a). Concentrations of $A$. australis accumulate in close proximity to rip systems which may also transport cells entrained in the water column further offshore (Talbot \& Bate 1987). When rips discharge into relatively calm water, A. australis cells sink due to a reduction in air bubble formation (Talbot \& Bate 1988b). Talbot \& Bate (1989) also describe the shift in the spatial distribution of $A$. australis during a 10-d storm-calm-storm cycle. During this study, $51 \%$ of the inshore population was temporally transported behind the breaker line. Accumulation of material behind the breakers is thus a potentially rich source of food to mysids foraging in this zone.

Although Anaulus australis forms high concentrations inside the breaker line, the gregarious Mesopodopsis slabberi is only rarely present in this inshore zone (Wooldridge 1983). Conditions are probably unfavourable due to turbulent surf, abrasion by suspended particles, mechanical dislodgement of larvae from the broodpouches of females, and suspension of sand particles which may interfere with feeding (Clutter 1967).

During daylight, Mesopodopsis slabberi occurred in gullies and under overhangs of reefs which were present in water of 15 to $20 \mathrm{~m}$ depth along the study transect. Few or no mysids were taken over the sandy bottom away from reef systems. The general absence of $M$. slabberi over the sandy floor of the bay may possibly be attributed to the distribution of predators such as juvenile Argyrosomus hololepidotus which were abundant throughout the year in the shallow waters of the bay (Smale 1984). This teleost is an epibenthic feeder foraging over sandy substrates, with $M$. slabberi forming a major prey item.

Berril (1968) recorded mysids hiding amongst shells, rocks, beds of algae and mangrove roots, while field studies by Glass (1971) and Stein (1977) have illustrated the strategic benefits of reefs and other protective structures to prey species. Reefs may thus form a relative sanctuary for Mesopodopsis slabberi providing consealment from major predators such as Argyrosomus hololepidotus.
Campbell \& Bate (1988) have estimated primary production in the inner Sundays River surfzone as 120000 $\mathrm{g} \mathrm{C} \mathrm{m} \mathrm{yr}^{-1}$, while primary production between the breaker line the outer limit of riphead activity was estimated as $100000 \mathrm{~g} \mathrm{C} \mathrm{m}^{-1} \mathrm{yr}^{-1}$. Other sources of carbon input into the Sundays River surfzone are relatively small, the total available pool of carbon being ca $230000 \mathrm{~g} \mathrm{C} \mathrm{m}^{-1} \mathrm{yr}^{-1}$ (McLachlan \& Romer in press).

Mesopodopsis slabberi feed actively on both settled and suspended Anaulus australis cells in the laboratory and show an initial linear ingestion response to increasing food concentrations (Webb et al. 1987). Estimates of the effects of $M$. slabberi grazing on $A$. australis are restricted by the patchiness of both grazer and diatom, but the following possible scenario may be described. M. slabberi aggregate at night in the $200 \mathrm{~m}$ wide zone between the 6 and $10 \mathrm{~m}$ depth contours. A $1 \mathrm{~m}$ wide strip of this region has an approximate volume of $1600 \mathrm{~m}^{3}$ and, at an average concentration of 65 adult and 510 juvenile $M$. slabberi $\mathrm{m}^{-3}$ (Wooldridge 1983), would theoretically contain 104000 and 816000 mysids respectively. Mean abundance was determined from 20 samples collected over 2 yr at 6 to $10 \mathrm{~m}$ depth off Sundays River beach. Ingestion rates of adult and juvenile mysids of 10 and $5 \mathrm{~mm}$ body length are taken from Webb et al, (1987) using the lowest experimental cell concentration $\left(1.76 \times 10^{4}\right.$ cells $\left.\mathrm{ml}^{-1}\right)$. A australis biomass is 2000000 cells $\mathrm{mg}^{-1}$ dry mass with carbon equal to $40 \%$ dry mass (Campbell 1988). Using these values, $M$. slabberi could consume $51 \mathrm{~g} \mathrm{C} \mathrm{d}^{-1}$, which on an annual basis, is ca $70 \%$ of the total organic carbon consumption of the macrofaunal trophic assemblage in the Sundays River surfzone (McLachlan \& Romer in press). Although macrofauna only account for $11 \%$ of the total carbon budget (McLachlan and Romer in press), mysid shrimps clearly occupy a key position in the macrofaunal foodweb.

Acknowledgements. We express our sincere thanks to Renzo Perissinotto for assistance in the field and laboratory, and to our colleagues who pulled nets at sea. Acknowledgements are also extended to SCUBA divers Deon van der Merwe and Bruce Tomalin. Financial assistance from the Department of Environmental Affairs and the University of Port Elizabeth is acknowledged.

\section{LITERATURE CITED}

Angel, M V (1985). Vertical migrations in the oceanic realm: possible causes and probable effects. In: Rankin, M. A. (ed.) Migration: mechanisms and adaptive significance. Cont. mar. Sci. Univ. Tex. (Supp.) 27: 45-70

Berril, M. (1968). The schooling and antipredatory behaviour of mysid shrimp. Ph.D thesis, Princeton University, Princetown

Campbell, E. E. (1988). The estimation of phytomass and primary production of a surfizone. Ph.D thesis, University of Port Elizabeth, Port Elizabeth 
Campbell, E. E., Bate, G. C. (1988). The estimation of annual primary production in a high energy surfzone. Botanica Mar. 31: $337-343$

Clutter, R. I. (1967). Zonation of nearshore mysids. Ecology 48: $200-208$

Clutter, R. I. (1969). The microdistribution and social behaviour of some pelagic mysid shrimps. J. exp. mar. Biol. Ecol. 3: $125-155$

Enright, J. T (1977). Diurnal vertical migration: Adaptive significance and timing. Part 1 . Selective advantage: a metabolic model. Limnol. Oceanogr. 22 (5): 856-872

Enright, J. T., Honegger, H. W. (1977). Adaptive significance and timing. Part 2. Test of the model: details of timing. Limnol. Oceanogr. 22 (5): 873-886

Glass, N. R. (1971). Computer analysis of predation energetics in the largemouth bass. In: Patten, B. S. (ed.) Systems analysis and simulation in ecology, Vol. 1. Academic Press, New York, p. 325-363

Hamner, W. M., Carleton, J. H. (1979). Copepod swarms: attributes and role in coral reef ecosystems. Limnol. Oceanogr. 24: 1-14

Hamner, W. M., Hauri, I. R. (1981). Long-distance horizontal migration of zooplankton (Scyphomedusae, Mastigias). Limnol. Oceanogr. 26: 414-423

Hutchinson, G. E. (1967). A treatise on limnology, Vol. 2. John Wiley, New York

Mauchline, J. (1980). The biology of Mysids and Euphausids. In: Blaxter, J. H. S., Russell, F. S., Yonge, M. (eds.). Advances in marine biology, Vol. 18. Academic Press, New York

McLachlan, A. (1983). The ecology of sandy beaches in the Eastern Cape, South Africa. In: McLachlan, A., Erasmus, T (eds.) Sandy beaches as ecosystems. Junk, The Hague, p. $539-546$

McLachlan, A., Romer, G. (in press). Trophic relationships in a high energy beach and surf zone ecosystem. In: Barnes, M., Gibson, R. (eds.) Trophic relationships in the marine environment. Aberdeen University Press, Aberdeen

Morgan, M. D., Threlkeld, S. T. (1982). Size dependent horizontal migration of Mysis relicta. Hydrobiologia 93: 63-68

Ringelberg, J. (1980). Introductory remarks: Causal and teleological aspects of diumal vertical migration. In: Kerfoot, W C. (ed.) Evolution and ecology of zooplankton communities University Press of New England, Hanover, p. 65-68

Siebeck, W., Ringelberg, J. (1969). Spatial orientation of planktonic crustaceans. 1. The swimming behaviour in a

This article was submitted to the editor horizontal plane. 2. The swimming behaviour in a vertical plane. Int. Verein. Theoret. Angew. Limnol. Verhandel. 17. $831-847$

Smale, M. J. (1984). Inshore small mesh trawling survey of the Cape south coast. Part 3. The occurrence and feeding of Argyrosomus hololepidotus, Potatomus saltatrix and Merluccius capensis. S. Afr. J. Zool. 19: 170-179

Stein, R. A. (1977). Selective predation, optimal foraging and the predator-prey interaction between fish and crayfish. Ecology 58: 1237-1253

Talbot, M. M. B., Bate, G. C. (1986). Diel periodicities in cell characteristics of the surfzone diatom Anaulus birostratus: their role in the dynamics of cell patches. Mar. Ecol. Prog. Ser. 32: 81-89

Talbot, M. M. B., Bate, G. C. (1987). The spatial dynamics of surf diatom patches in a medium energy cuspate beach. Botanica Mar. 30: 459-465

Talbot, M. M. B., Bate, G. C. (1988a). The use of false buoyancies by the surf diatom Anaulus birostratus in the formation and decay of cell patches. Estuar. cstl Shelf Sci. 26: 155-167

Talbot, M. M. B., Bate, G. C. (1988b). Distribution patterns of the surf diatom Anaulus birostratus in an exposed surfzone. Estuar. cstl Shelf Sci. 26: 137-153

Talbot, M. M. B., Bate, G. C. (1989). Beach morphodynamics and surf-zone diatom populations. J. exp. mar. Biol. Ecol. 129: 231-241

Webb, P., Perissinotto, R., Wooldrige, T. H. (1987). Feeding of Mesopodopsis slabberi (Crustacea, Mysidacea) on naturally occurring phytoplankton. Mar Ecol. Prog. Ser. 38: $115-123$

Williams, R., Collins, N. R. (1984). Distribution and variability in abundance of Schistomysis spiritus (Crustacea, Mysidacea) in the Bristol channel in relation to environmental variables, with comments on other mysids. Mar. Biol. 80: 197-206

Wittman, K. J. (1977). Modification of association and swarming in north Adriatic Mysidacea in relation to habitat and interacting species. In: Keegan, B. F., Ceidigh, P. E., Boaden, P. J. S. (eds.) Biology of benthic organisms. Pergamon Press, Oxford

Wooldridge, T H. (1983). Ecology of beach and surfzone mysid shrimps in the Eastern Cape, South Africa. In: McLachlan, A., Erasmus, T. (eds.) Sandy beaches as ecosystems. Junk, The Hague, p. 449-460

Manuscript first received: June 2, 1989

Revised version accepted: January 19, 1990 